\title{
Research Risk Factors and Management Competence of Vietnam Commercial Banks from 2006-2020
}

\author{
Pham Duc Trung \\ Department of Natural Resources \& Environment Economic, Ho Chi Minh City University of Natural Resources \& Environment, Ho \\ Chi Minh City 760000, Vietnam
}

\begin{abstract}
Banks are various credit institutions that perform all bank activities and other business activities. According to the nature and objectives of operation, types of banks include all the commercial banks, development banks, investment banks, policy banks, joint stock banks and other types of banks.
\end{abstract}

Key words: Risk, risk management, commercial banks of Vietnam.

\section{Introduction}

In recent years, the operation of Vietnam Commercial Bank system is in the process of innovation in order to adapt to the market economy, contributing significantly to creating a momentum for National Economy Development. However, besides that, great complex changing is the issue of risk in Commercial Bank system of Vietnam and banks may become the victim of the market economy without effective methods [1-4].

\section{Subjects, Methods and Data of Study}

To assess the management risk of all the commercial banks, commerce banks of Vietnam have risk exposure and weakness risk management capabilities [1-8]. Research the basic risks issues in the activities of commercial banks and the risk management competence of the commercial banks in Vietnam based on the analysis of economic activity and comparable statistics.

\subsection{Risks in Business Operations of All the Commercial Banks}

From the study, the characteristics of business operations of the Bank of Commerce may be realized

Corresponding author: Pham Duc Trung, Ph.D., research field: economic, marketing, finance and bank. that the risk is always associated with each bank's professional operation in the operating of commerce bank $[9,10]$. The majority of economists agreed that the concept of risk in the business operations of the Bank of Commerce was "occurrence unexpected events and cause damage to the bank". The level and nature of different risks will cause the consequences which are not the same, but are always very harmful because of the impact on the bank's reputation and its ability to spread. Learning about the types, causes and consequences of risks in business activity will answer some questions why authors have to administrate and improve the risk management of commercial banks [10].

\subsection{The Types of Risks in the Business Operations of Commercial-Banks}

\subsubsection{Credit-risk}

Credit-risk refers to the risk that the client (the debtor) who received loans from the bank can't repay the capital and interest rate, causing losses to the Bank [9]. Credit-risk accounts the largest proportion and comes from the characteristics of bank credit. In fact, credit activities usually account for the largest share of business activities of the Bank of Commerce [1-8]. Basically, credit-risk occurs when borrowers do not have the ability to pay interest rate and repay the debt 
or both. Except for a few rogue clients, the majorities of customers in good business and production operation have a healthy financial situation and make full payment to the bank. But still a force majeure situation could not lead to a timely repay to the banks. So, credit-risk is objective, existing in parallel with bank credit, and Commercial Bank can only accept limited and required credit-risk in certain extent only.

\subsubsection{Liquidity-risk}

Losses are caused to the bank when the actual liquidity needs are exceeding expected levels, or the bank does not meet the demand for payment or customer withdrawals [9]. However, in reality, liquidity-risk is less common by the activity on the interbank money market. If occurs, it will be a very serious problem, because it can lead to the collapse of the Commercial Bank when customers flock to the teller.

\subsubsection{Market-risk}

Losses caused to the bank with unforeseen fluctuations of the market, including interest rate and the rate of exchange risk.

From the results of other studies, interest rate and exchange rate have the same points as the market is always changing, depending on supply factors demand and foreign capital [9].

Currently, interest rates and exchange rates are managed by the State Bank [10], thus the Commercial Bank are not interested in interest rate risk.

\subsubsection{Operational-risk}

Losses caused to the bank during the operations of Commercial Bank [9], such as, the difference in information and the unreasonable in technical processes. Thus, the first bank and large-scale progress in the world is always researching and optimizing operational procedures on the basis of the organizational framework of the best suited for each type of bank.

\subsection{Statement of the Problem}

Risk happening in business operations of
Commercial Bank may arise from the intrinsic characteristics of the bank business and be influenced by the conditions and the natural environment, economy and society $[9,11,12]$. Based on that, the bank financial experts have divided the causes of risk into three groups as follows:

\subsubsection{Objective-reasons}

This is the causes of risk such as natural disasters or the changing of social and economic management policy of government, harmful to customers or directly to the banks. So, Commercial Banks have to overcome the consequences of risk

\subsubsection{Causes-from-customers}

As the customers do not want to make the commitment to the bank, the bank will have to bear the loss [9]. In fact, it is very easy to notice that in the business, productively operation and life of the customer is likely to encounter risks and at least a part of that risk will be shared to the banks $[11,12]$.

\subsection{The Cause of the Banks Themselves}

For all the banks in the world, this cause is considered the most important because the ability to prevent and mitigate risks depends primarily on the capacity of banks [9]. From the merger policy, management to the level of technology and professional ethics of officers and employees working in the banks is the factor affecting the level of risk of each bank. Banks with high technological level having various product categories combined with the human resources of good qualities always have the low risk level. Even if risk occurs, banks can still limit the consequences throughout economic measures and market to minimize financial losses and reputation.

\subsection{Assess the Impact of Causes and Risk Management in Business Operations of Commercial Bank}

\subsubsection{Manage Risk and Risk Management}

Risk management is the use of tools, methods and processes necessary in the specific business activity in order to minimize the possibility of damage to the bank 


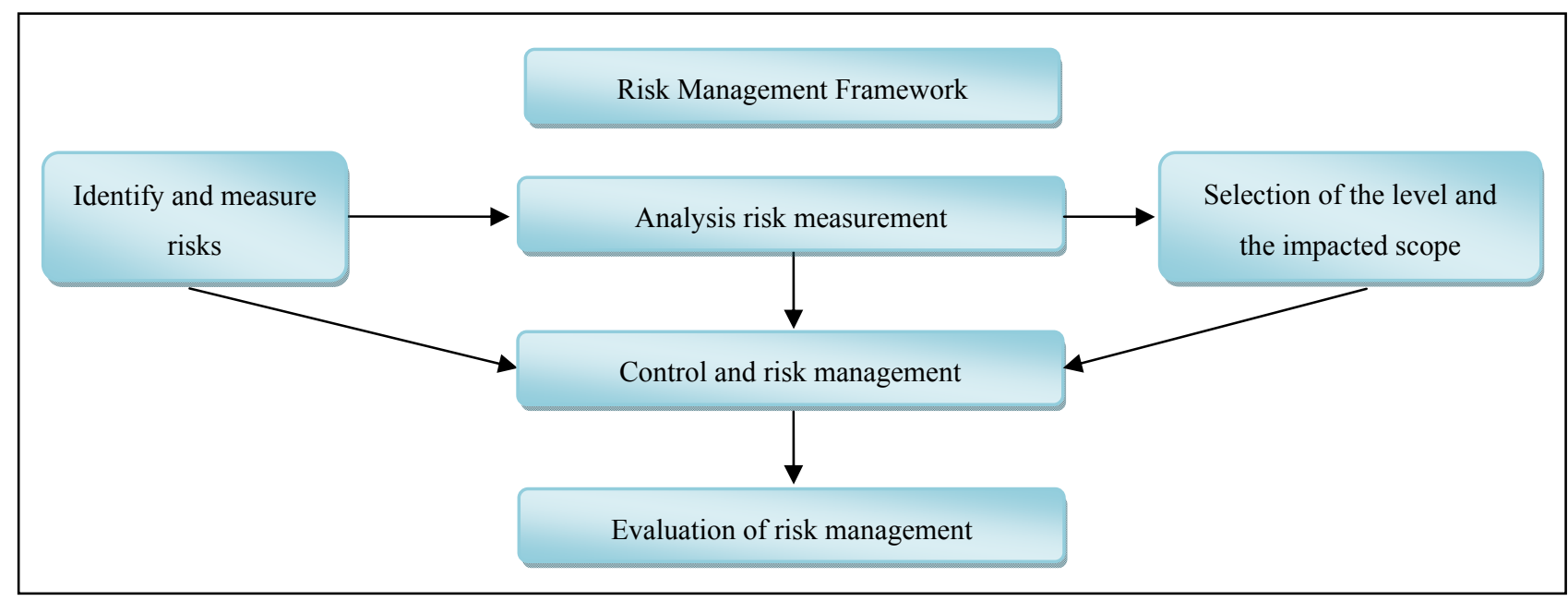

$[9,10]$. Research on state management perspective and risk management can be done through stricter regulations on business operations of the bank; its restriction on banking activities in the region is considered safe and effective.

2.5.2 Competences and Risk Management of Commercial Banks

Almost all executives believed that the risk management capability is expressed through risk efficient control or the effectiveness of specific management measures in the strategy of the risk managers $[9,10]$.

\section{Results}

3.1 General Characteristics of the Vietnam Commercial Banks on Risk Management

Risk management is the use of tools, methods and processes necessary in the specific business activity in order to minimize the possibility of damage to the bank $[9,10]$. Research on state management perspective and risk management can be done through stricter regulations on business operations of the bank; its restriction on banking activities in the region is considered safe and effective.

2.5.2 Competences and Risk Management of Commercial Banks

Almost all executives believed that the risk management capability is expressed through risk efficient control or the effectiveness of specific management measures in the strategy of the risk managers $[5,11]$.

\subsection{Cause Affect Business Operations of Commercial Banks of Vietnam}

Vietnam commercial banks with low capital size and capital adequacy ratio below the international rules are shown in Table 1 [10]. Authors have restricted the ability of credit, financing for business activities and also met every obstacle. It is difficult to expand the scope of activities and bank technology innovations, and even more difficult to compete with foreign banks on the territory of Vietnam.

In Table 2, the commercial banks with the motto of "borrowing for lending" have increasingly focused on the diversification of forms of capital mobilization from demand deposits with a term to many different period as deposit certificates, savings of VND and foreign currencies [1-8]. Currently, the interest rates of commercial banks are commonly at $7.5 \%$ /year for VND deposits to ensure liquidity.

\subsection{Analysis and Assessment of Interest Rate Risk}

Interest rate policy is one of the important policies to regulate the economy [10], especially for an economy where credit channel plays an important role for the supply of capital for production and business activities and also is the main source of profit for the Bank. According to assessments of experts, the issue of 
Table 1 The capital safety factor of some bank.

\begin{tabular}{lllllll}
\hline \multicolumn{1}{l}{ The capital safety factor of some bank at the end of this year 2006 . (Unit: \%) } \\
\hline Vietcombank & BIDV & Agribank & MHB & ACB & Sacombank & EAB \\
12 & 6.7 & 7.2 & 9.44 & 6.19 & 11.07 & 14.36 \\
\hline
\end{tabular}

Source: State Bank of Vietnam.

Table 2 The situation of capital mobilization. (Unit: 1,000.000 VND)

\begin{tabular}{llllllll}
\hline Standard & & BIDV & $\begin{array}{l}\text { Vietcombank } \\
\text { bank }\end{array}$ & Agribank & $\begin{array}{l}\text { Sacombank } \\
\text { bank }\end{array}$ & ACB & MHB \\
\hline \multirow{2}{*}{$\begin{array}{l}\text { Capital } \\
\text { mobilization }\end{array}$} & Year 2006 & 116.862 & 152.579 & 233.337 & 34.591 & 29.390 & 16.409 \\
& Year 2007 & 243.055 & 159.528 & 305.671 & 55.692 & 55.283 & 25.129 \\
& Increase (\%) & 117 & 104 & 131 & 161 & 188 & 153 \\
\hline
\end{tabular}

Source: BIDV, ACB, Vietcombank, Vietinbank, MHB, Agribank; Annual Report, 2006-2007.

racing interest rates in the past year between the Commercial Banks is not of the same bank law, and CPI index falls.

The main reason leading to this situation is the availability of unevenly distributed capital in banks. Some banks are under capitalized, while other banks excess capital but interbank money market is undeveloped. The lender under the credit limit should be adjusted slowly, so many cases which do not always move from bank to bank capital. The result is that the bank lacks the capital in order to boost capital mobilization forms and offering attractive interest rates, and this problem led to an interest rate race of other banks [1-8].

\subsection{Causes of Interest Rate Risk}

Interest rate risk is one of the specific risks of the Commercial Bank of Vietnam. This risk occurs when market interest rates change, especially changes in the direction of increasing which are the main cause of the interest rate risk $[9,11,12]$.

Changing in market interest rates can impact negatively on bank profits that can increase funding costs, reduce income from assets, lower the value of bank capital. So, the volatility of interest rates impact all balance statement sheet and income statements-of-banks [9].

Financial and currency markets had not developed, and evident in financial instruments is still poor in tiny type and transaction volume $[11,12]$.

Interest rate risk prevention matters are too low in Vietnam Commercial Bank.

\subsection{Results of Analysis and Liquidity Risk Assessment}

Liquidity risk is the risk that the bank could not afford to meet liabilities when payments [9]. Thus, business forecasting and market analysis of the Vietnam commercial banks are still limited; the link between Vietnam commercial banks to ensure payment security is weak $[9,10]$ and the useful management tools are short [10].

\subsection{Results of Analysis and Assessment of Operational-risk}

- Because bank staffs perform operational tasks and they are not authorized or approved by the competent exceed permit, they fail to comply with regulations and business processes of the Bank and the current legislation [9];

- Do not comply with the rules, and procedures of support system.

\section{Discussions}

Vietnam Commercial Bank plays an important role to keep the blood of the economy in circulation, and is the bridge between the individual and the organizations [10].

The quality of human resources is considered the most important factor determining the risk 
management capacity of Vietnam Commercial Bank. Good financial capability enables commercial banks of Vietnam to mobilize large capital and allows conducting business operations diversity, not only reducing risk but also able to accept loss risks.

\subsection{Socio Economic Environment and Business}

Although the banks have the ability to have access to sufficient human resources and other factors, but the legal environment, socioeconomic unfavorable, the risk management capabilities appreciated though could not contribute effectively to the bank operation [10].

\subsection{The Business Model of Vietnam Commercial Banks}

The business model of Vietnam commercial banks today remains "monoculture". Besides, the training and employment of officials and employees are still inadequate compared to the needs of new business [1-8].

\section{Conclusions}

Through the study of the causes of risk due to poor management of Vietnam commercial bank and economic instability escalating, global food crisis, the collapse in the market for loans of property of Vietnam Bank, the Vietnam commercial Bank will certainly be affected, and Vietnam commercial banks will also have to face the credit risk of real estate loans, liquidity risk, operational risk, etc. [9].

Last time, authors saw that the risk factors are adjacent to commercial banks, inflation, banks received negative real interest rates, and liquidity at an alarming rate; some banks have almost no activities that rely on the resilience and stability of the economy; and the training and employment of officials and employees are still inadequate compared to the needs of new operation.

Next time, authors can see clearly that the control and prevention of risks to the commercial bank of Vietnam, which is very necessary.

\section{References}

[1] Agricultural Bank of Vietnam, Annual report, 2006-2007.

[2] Asian Commercial Bank of Vietnam, Annual report, 2006-2007.

[3] Bank for Foreign Trade of Vietnam, Annual report, 2006-2007.

[4] Bank for Investment and Development of Vietnam, Annual report, 2006-2007.

[5] East Asian Bank, Annual report, 2006-2007.

[6] Mekong Delta Housing Bank of Vietnam, Annual report, 2006-2007.

[7] Saigon Commercial Bank of Vietnam, Annual report, 2006-2007.

[8] Trade and Industry Bank of Vietnam, Annual report, 2006-2007.

[9] Basel Committee on Banking Supervision. 2016. Interest Rate Risk in the Banking Book.

[10] State Bank of Vietnam, Annual report, 2006- 2007.

[11] Cuc, P. T. 2012. Financial and Monetary Theory. Ho Chi Minh City: Phuong Dong Publishing House.

[12] Don, N. D. 2008. Financial and Currency Theory. Ho Chi Minh City: Statistics Publishing House. 